Article

\title{
Synthesis and Liquid Crystalline Properties of New Diols Containing Azomethine Groups
}

\author{
Issam Ahmed Mohammed ${ }^{1, *}$, Govindarajan Sankar ${ }^{1}$, Melati Khairuddean ${ }^{2}$ and \\ Abu Bakar Mohamad ${ }^{2}$ \\ 1 School of Industrial Technology, University Sains Malaysia, 11800 Penang, Malaysia \\ 2 School of Chemical Sciences, University Sains Malaysia, 11800 Penang, Malaysia \\ * To whom correspondence should be addressed; E-Mail: issam@usm.my; Fax: 604-6575854.
}

Received: 10 March 2010; in revised form: 30 March 2010 / Accepted: 6 April 2010 /

Published: 30 April 2010

\begin{abstract}
A series of new mesogenic azomethine diols were successfully synthesized by condensation reactions between various chloroalkanols and $N, N^{\prime}$-bis(4-hydroxy)benzylidene-o-toluidine (1). The structures of these compounds were confirmed by $\mathrm{CHN}$, FT-IR, ${ }^{1} \mathrm{H}-\mathrm{NMR}$, and ${ }^{13} \mathrm{C}-\mathrm{NMR}$ spectrophotometer. Their thermotropic liquid crystalline behavior was studied using differential scanning calorimetry (DSC) and polarizing optical microscope (POM). 4,4'-di(4-Hydroxybutoxy)- $N$-benzylidine-o-tolidine (2a) does not exhibit liquid crystalline properties. A nematic texture was observed for mesogenic diols $\mathbf{2 b}$, and 2d, whereas the diol $\mathbf{2 c}$ exhibits a smectic mesophase. The increase of terminal alkyl chain in these mesogenic diols leads to a decrease in the transition temperature.
\end{abstract}

Keywords: thermotropic liquid crystal; nematic phase; diols; azomethine

\section{Introduction}

Organic compounds exhibit thermotropic liquid crystalline (LC) properties when the molecules possess rod- or disc-like structure. The stabilization and polarizability are two of the most important factors in liquid crystal devices. Researchers have discovered that small molecules are also capable of exerting a significant impact on the molecular polarizability as well as the stabilization in the liquid crystalline compounds. Azomethine $(\mathrm{CH}=\mathrm{N})$ linkages present in the backbone provide an attractive class of high performance material. High thermal stability, excellent mechanical strength, and good 
optoelectronic properties are also attributed to the resonance stabilization of the Schiff's base unit [1]. However, these small molecules have certain drawbacks such as poor solubility that minimize their practical applications.

Small molecules (in this case, liquid crystal monomers) with geometrical anisotropy and high polarizability often exhibit one or more liquid crystalline phases besides the crystalline and isotropic phases [2]. Therefore, a terminal functional group such as a hydroxyl group is employed in order to enhance these features. One of the typical examples is the study on the effect of lateral hydroxyl groups on the mesomophism of azobenzene derivatives [3]. To our best knowledge, limited work has been performed on the compounds containing azomethine linkages and hydroxyls as the end group. With this background we decided to synthesize a series of novel $N, N^{\prime}$ bis(4-hydroxyl)benzylidine-otolidine derivatives and to investigate the liquid crystalline properties of the new diols.

\section{Result and Discussion}

\subsection{Synthesis and characterization}

Preparation of diols 2(a-d) is explained in Scheme 1. The structures of bisphenol $\mathbf{1}$ and the diols 2(a-d) were confirmed by elemental analysis (CHN), FT-IR, ${ }^{1} \mathrm{H}-\mathrm{NMR}$ and ${ }^{13} \mathrm{C}-\mathrm{NMR}$ spectrophotometry. Figure 1 shows four different IR spectra representing diols $\mathbf{1}, \mathbf{2 a}, \mathbf{2 b}$ and $\mathbf{2 d}$. In the obtained FT-IR spectra the disappearance of the $\mathrm{NH}_{2}$ and carbonyl absorption bands at $(3,336-3,472) \mathrm{cm}^{-1}$ and $1,667 \mathrm{~cm}^{-1}$ and the appearance of characteristic absorption bands at $1,620 \mathrm{~cm}^{-1}$ assigned to the presence of a $-\mathrm{CH}=\mathrm{N}$ bond could be observed. This correlates with the data obtained by Issam [4] and So et al. [5], where the absorption band for $-\mathrm{CH}=\mathrm{N}$ group is around $1,619 \mathrm{~cm}^{-1}$. The sharp absorption band at $(3,350-3,414) \mathrm{cm}^{-1}$ is attributed to the -OH group [6,7]. Absorption bands at $1,480 \mathrm{~cm}^{-1}$ and $1,592 \mathrm{~cm}^{-1}$, which is corresponds to aromatic $-\mathrm{C}=\mathrm{C}-$, indicates that an aromatic ring exists in the synthesized compound. The FT-IR data for the diols $\mathbf{2 ( a - d ) ~ a n d ~ t h e ~ r e a c t a n t s ~ a r e ~ g i v e n ~ i n ~}$ Experimental section.

Scheme 1. Synthesis of mesogenic diols 2 (a-d).
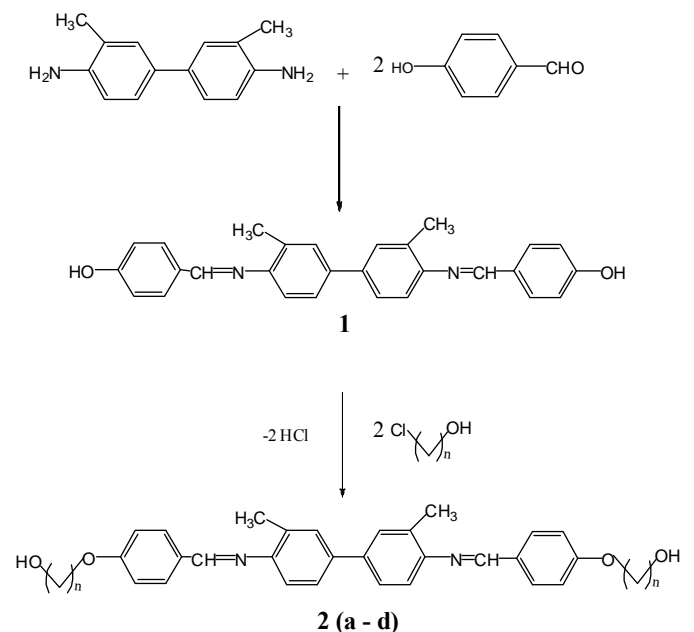

$$
\text { a: } n=4
$$

$$
\text { b: } n=6
$$$$
\text { c: } \mathrm{n}=8
$$$$
\mathrm{d}: \mathrm{n}=10
$$ 
Figure 1. The FT-IR spectra of (A) bisphenol 1 (B) diol 2a, (C) diol $\mathbf{2 b}$ and (D) diol $\mathbf{2 d .}$

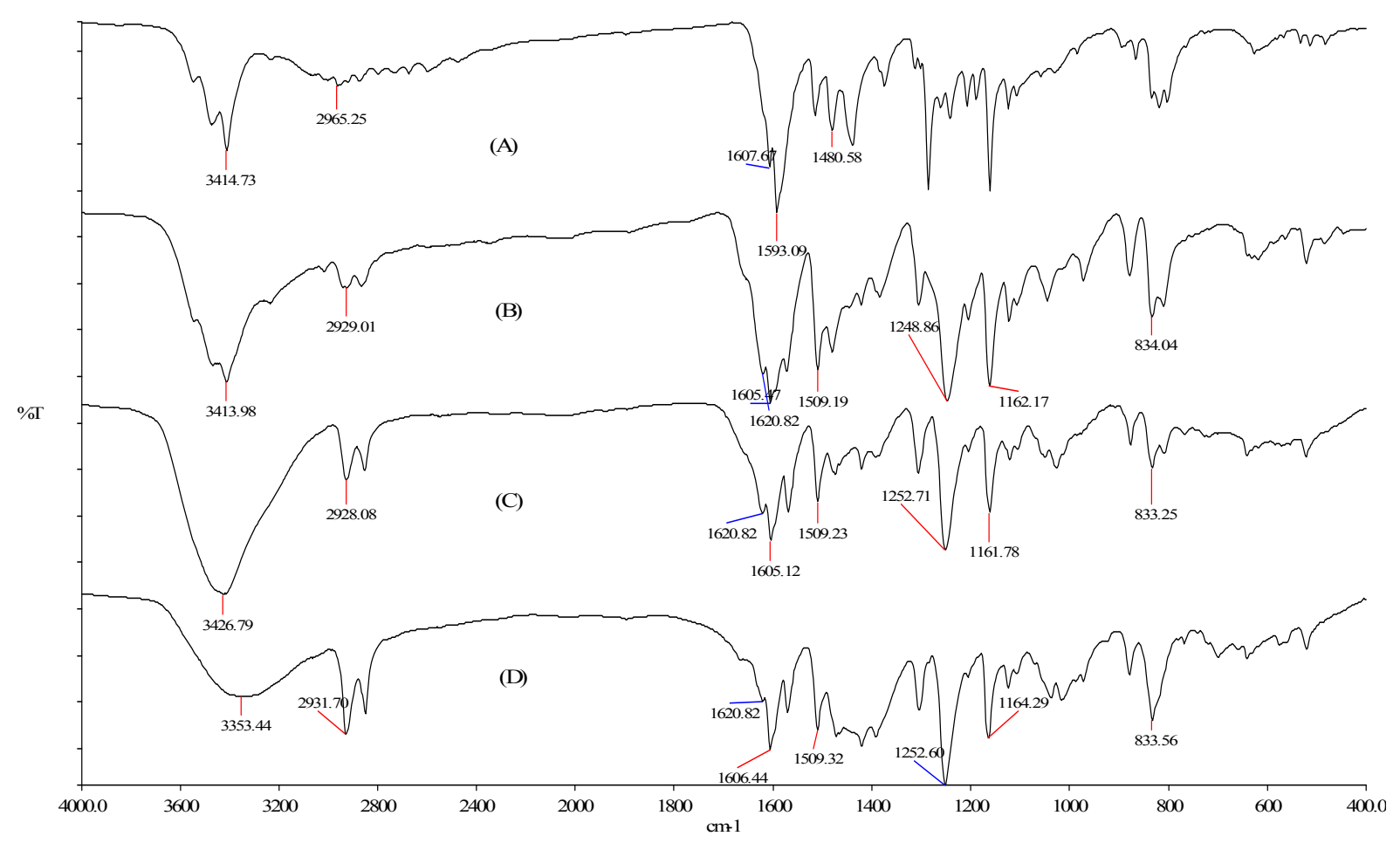

Figures 2 and 3 show typical examples of ${ }^{1} \mathrm{H}-\mathrm{NMR}$ and ${ }^{13} \mathrm{C}-\mathrm{NMR}$ spectra, corresponding to diol $\mathbf{2 b}$. In the ${ }^{1} \mathrm{H}-\mathrm{NMR}$ spectrum, the methylene protons in $\left(\mathrm{HO}-\mathrm{CH}_{2}-\right)$ and $\left(\mathrm{Ph}-\mathrm{O}-\mathrm{CH}_{2}-\right)$ appear at $3.57 \mathrm{ppm}$ and $4.05 \mathrm{ppm}$, respectively. This is similar to the data that obtained by Stamatoiu et al. [8]. The singlet peak at $8.65 \mathrm{ppm}$ is assigned to the azomethine $(-\mathrm{CH}=\mathrm{N}-)$ group [9]. The azomethine group appeared at higher field because the nitrogen atom is bonded to an aromatic ring and the nitrogen has a lone pair of electrons which enables it to delocalize into the aromatic ring. The bands of the -OH protons are not detected due to overlap with $\mathrm{C}-\mathrm{H}$ protons. However, we further confirm formation of hydroxyl group by FT-IR which indicates the absorption band at 3,420 $\mathrm{cm}^{-1} .{ }^{1} \mathrm{H}-\mathrm{NMR}$ data for the diols 2 (a-d) are given in the Experimental section and the properties are summarized in Table 1.

Figure 2. ${ }^{1} \mathrm{H}-\mathrm{NMR}$ spectrum of diol $2 \mathrm{~b}$.

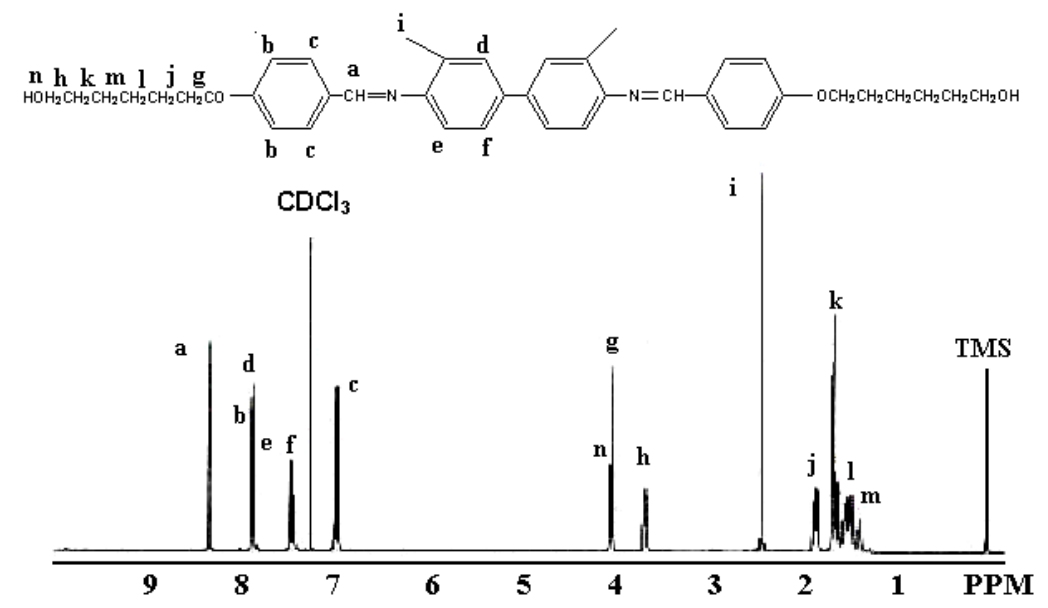


Figure 3. ${ }^{13} \mathrm{C}-\mathrm{NMR}$ spectrum of diol $2 \mathrm{~b}$.

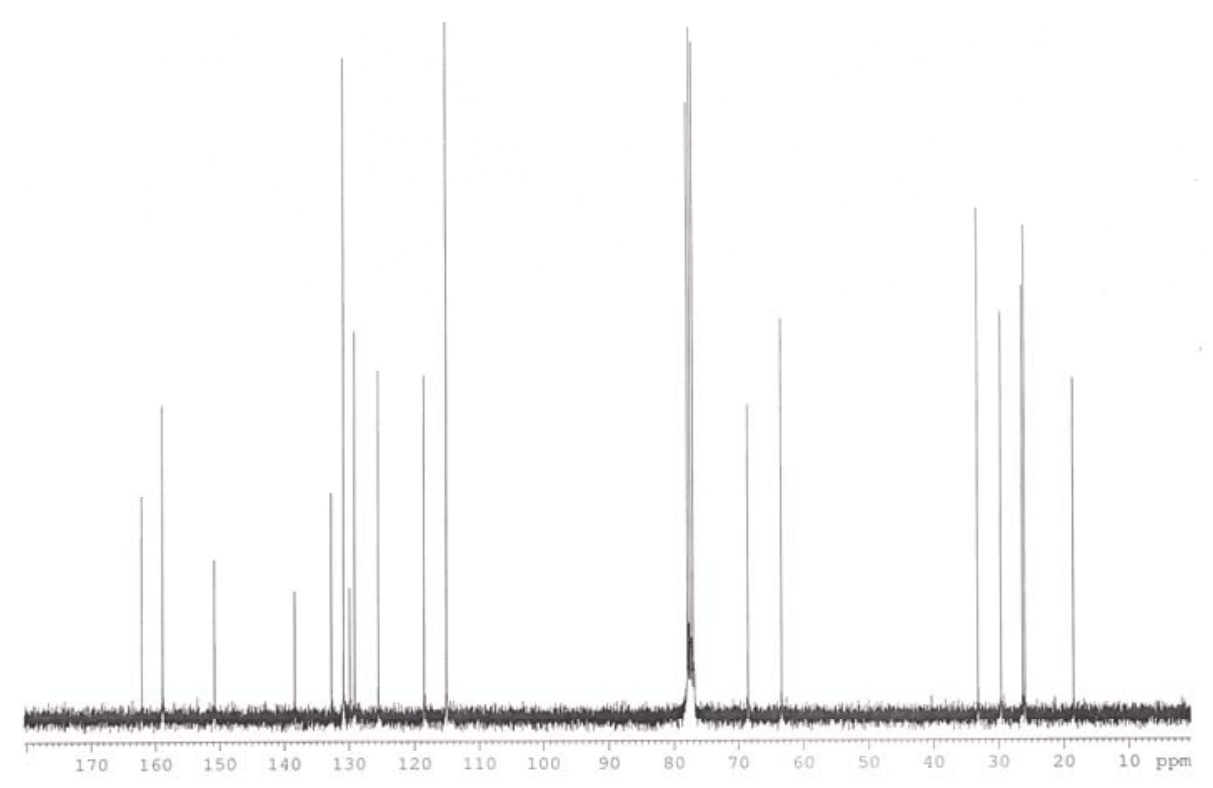

Table 1. Physical properties and CHN data for diols 2 (a-d).

\begin{tabular}{|c|c|c|c|c|c|}
\hline \multirow{2}{*}{ Mesogenic diol } & \multicolumn{2}{|c|}{ CHN } & \multirow{2}{*}{ Color } & \multirow{2}{*}{$\begin{array}{c}\text { Yield } \\
(\%)\end{array}$} & \multirow{2}{*}{$\begin{array}{c}\text { Melting Point } \\
\left({ }^{\circ} \mathrm{C}\right) \\
\end{array}$} \\
\hline & Calculated (\%) & Found (\%) & & & \\
\hline $\begin{array}{l}\text { N,N'-bis(4-hydroxyl) } \\
\text { benzylidine-o-tolidine (1) }\end{array}$ & $\begin{array}{l}\mathrm{C}: 80.0, \mathrm{H}: 5.70 \\
\mathrm{~N}: 6.66 .\end{array}$ & $\begin{array}{l}\mathrm{C}: 79.7, \mathrm{H}: 5.60 \\
\mathrm{~N}: 6.56 .\end{array}$ & Yellow & 88 & $281-282$ \\
\hline $\begin{array}{l}\text { 4-4-di(4-hydroxybutoxy)-N- } \\
\text { benzylidene-o-tolidine (2a) }\end{array}$ & $\begin{array}{l}\mathrm{C}: 76.59, \mathrm{H}: 7.09 \\
\mathrm{~N}: 4.96 .\end{array}$ & $\begin{array}{l}\mathrm{C}: 76.43, \mathrm{H}: 7.14, \\
\mathrm{~N}: 5.06 .\end{array}$ & Yellow & 58 & $242-244$ \\
\hline $\begin{array}{l}\text { 4-4-di(6-hydroxyhexoxy)-N- } \\
\text { benzylidene-o-tolidine (2b) }\end{array}$ & $\begin{array}{l}\mathrm{C}: 77.14, \mathrm{H}: 7.74, \\
\mathrm{~N}: 4.51 .\end{array}$ & $\begin{array}{l}\mathrm{C}: 77.30, \mathrm{H}: 7.79, \\
\mathrm{~N}: 4.50 .\end{array}$ & Brown & 70 & $160-162$ \\
\hline $\begin{array}{l}\text { 4-4-di(8-hydroxyoctoxy)-N- } \\
\text { benzylidene-o-tolidine (2c) }\end{array}$ & $\begin{array}{l}\mathrm{C}: 78.1, \mathrm{H}: 8.28, \\
\mathrm{~N}: 4.14\end{array}$ & $\begin{array}{l}\mathrm{C}: 78.28, \mathrm{H}: 8.11 \\
\mathrm{~N}: 4.20 .\end{array}$ & Yellow & 68 & $119-120$ \\
\hline $\begin{array}{l}\text { 4-4-di(10-hydroxydecoxy)-N- } \\
\text { benzylidene-o-tolidine (2d) }\end{array}$ & $\begin{array}{l}\mathrm{C}: 78.68, \mathrm{H}: 8.74, \\
\mathrm{~N}: 3.82 .\end{array}$ & $\begin{array}{l}\mathrm{C}: 78.60, \mathrm{H}: 8.90, \\
\mathrm{~N}: 3.80 .\end{array}$ & Yellow & 81 & $108-109$ \\
\hline
\end{tabular}

\subsection{Thermal and optical analysis}

The mesophases of the diols $\mathbf{2 ( a - d )}$ were studied by polarizing optical microscope (POM) and differential scanning calorimetry (DSC). Table 2 shows the mesophase confirmation and the transition temperatures for diols 2(b-d). DSC analysis was carried out for all diols obtained and Figure 4 shows the observed transition temperature for diol $\mathbf{2 b}$. The crystal phase to nematic phase transition temperature ( $\mathrm{Cr}-\mathrm{N})$ and nematic phase to isotropic phase transition (N-I) temperature is observed under POM. When the diols are observed under POM at $5{ }^{\circ} \mathrm{C} / \mathrm{min}$ (to correlate with the DSC rate), the results revealed that the diols $\mathbf{2 b}$, and $\mathbf{2 d}$ exhibit a nematic liquid crystal phase, diol $\mathbf{2 c}$ exhibits a smectic liquid crystal phase, whereas diol 2a do not show any liquid crystalline behavior, but simply changes from a solid to an isotropic fluid. Compounds that exhibit liquid crystalline behavior are due to their high aspect ratio (length to breadth ratio). The POM images for all obtained compounds are shown in Figure 5. It is worth mentioning that similar studies have been done on liquid crystals with 
four aromatic rings in the rigid core and when a three and four carbon alkyl chain is added to its terminal end they did not exhibit liquid crystal phases [4]. The addition of the flexible chain length decreased the melting point of these diols. This observation is supported by the previous research [1012]. The lateral substituents introduced into mesogen molecules depress the thermal stability of the mesophases, it is due to the overall anisotropic broadening of the molecule will influence cooperative packing needed in the structures that form mesophase $[13,14]$.

Figure 4. DSC thermogram of diol $2 b$.

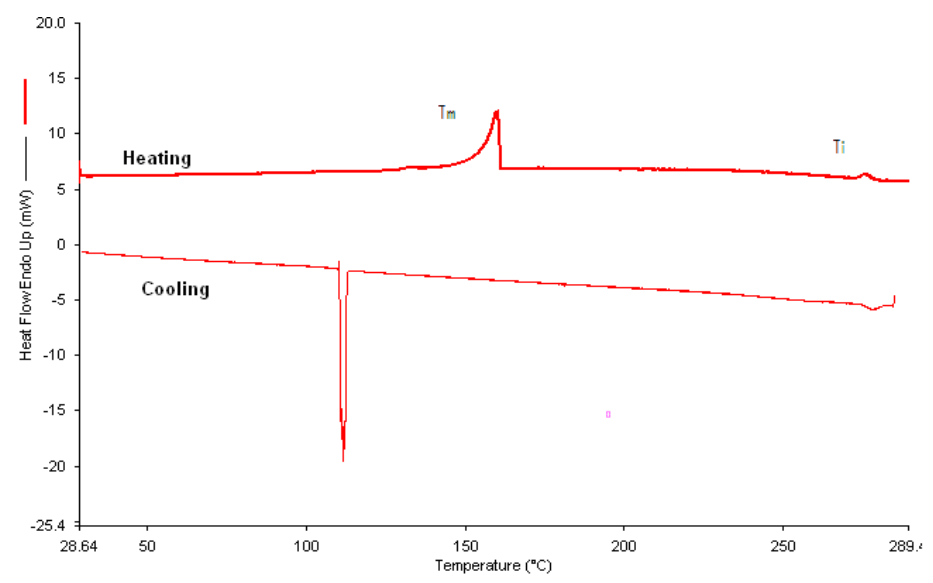

Figure 5. Polarized optical micrographs of (a) diol 2a, (b) diol 2b, (c) diol 2c, and (d) diol $2 \mathbf{d}$.

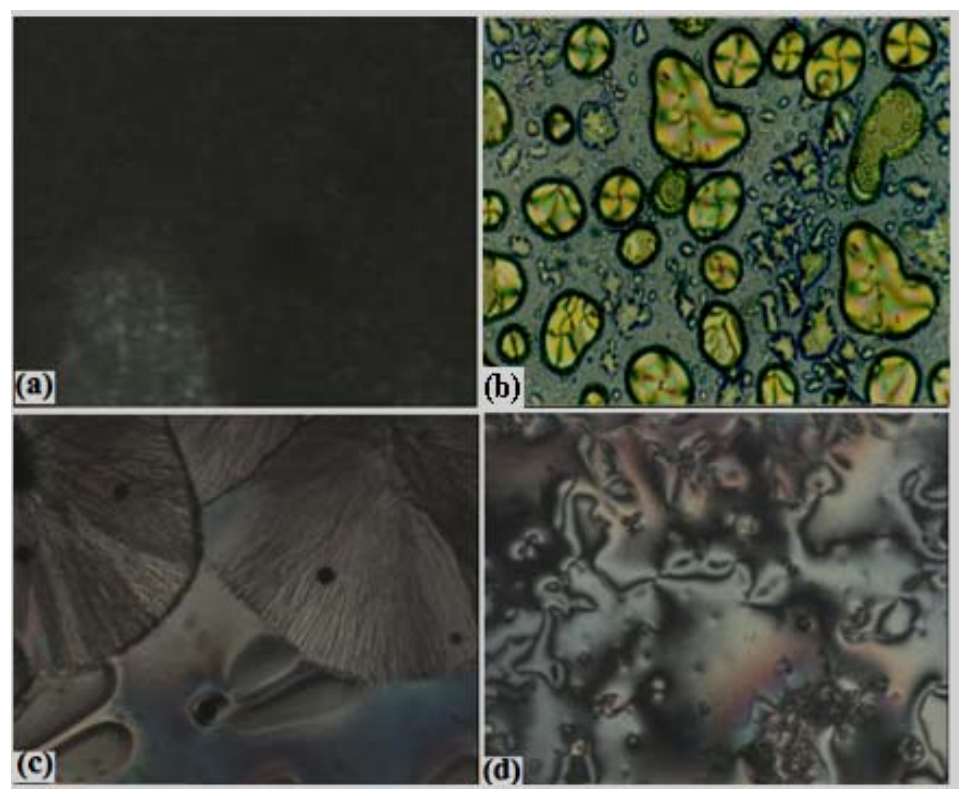

The effect of a flexible substituent in depressing the mesophase stability is greater in more ordered phases such as smectics than nematics [15]. The alkylation of the flexible chain gives a larger nematic phase range when it is added at the terminal end (located as far as possible from the rigid part of the molecule) [16]. However, the effect of dilution by adding the length of flexible chain has a limit, and further addition of the carbon chain length will increase the transition temperatures [17]. Therefore, it could be predicted that further addition of flexible chain length might increase the transition temperature point. Nevertheless, there are cases that the transition temperature will increase with increase in the alkyl chain length as reported in the works of Dave et al. [18]. Chemical crosslinking 
imposes additional constraints on the motion of chain segments which reduced the free volume that caused an increased in transition temperature [14]. Nevertheless, the clearing temperatures decrease with increasing spacer lengths too [11]. The linker group used in our present work is $\mathrm{CH}=\mathrm{N}$ (an azomethine group). This linker group generally will have a higher transition temperature when compared to the ester linker group (COO). In the latter the oxygen atom of the central carbonyl group will be bumped into the non-bonded sides of the adjacent hydrogens in the aromatic ring, thereby causing considerable strain on the molecules [18]. This will cause some twist around the C-O bond and force the benzene ring with ester linkage out of the plane in the molecules. Thus reduces the coplanarity of the molecule and the broadening of rigid core. All diols used are of an even number of carbon alkyl chain length $(\mathrm{n}=4,6,8$, and 10) hence the odd-even effect is not shown in the melting points trend. The odd-even effect is exhibited when a subsequent increase in flexible chain length (one by one carbon atom) will result in an inconsistent increase or decrease in transition temperature. The methyl group that is bonded to each aromatic ring also plays an important role in decreasing the transition states. In this research, one of the starting materials (o-tolidine) possesses two methyl groups where each one is bonded to the aromatic ring in the meta position will increase molecular broadening of the rigid core, such that intermolecular interactions are responsible for mesomorphism decreased as the intermolecular separation increases. This would in turn increase the entropy $(\Delta S)$ of the nematic to isotropic phase transition. As explained earlier, 4-4'-di(6-hydroxyhexoxy)- $N$-benzylidene-o-tolidine (diol 2b), 4-4'-di(8-hydroxyoctoxy)- $N$-benzylidene-o-tolidine (2c) and 4-4'-di(10-hydroxydecoxy)$N, N^{\prime}$-benzylidene-o-tolidine (2d), only show marbled texture when heated above its melting point. The isotropic points for diols $2(\mathbf{b}-\mathbf{d})$ are $275.2{ }^{\circ} \mathrm{C}, 231.0{ }^{\circ} \mathrm{C}$ and $251.0{ }^{\circ} \mathrm{C}$, respectively. Diols $2 \mathbf{b}$ and $2 \mathbf{d}$ exhibit typical nematic texture and no trace of smectic structure was seen in these diols. Diol 2a do not show liquid crystalline behavior, but only melts at $242.11^{\circ} \mathrm{C}$. The reason that this compound does not exhibit any liquid crystal phase because is presumably because the carbon chain is not long enough.

Table 2. Transition temperatures of diols $\mathbf{2}(\mathbf{a}-\mathbf{d})$.

\begin{tabular}{|l|c|c|c|c|c|}
\hline \multirow{2}{*}{ Mesogenic diol } & \multirow{2}{*}{$\mathbf{C r - N}\left({ }^{\mathbf{0}} \mathbf{C}\right)^{*}$} & \multirow{2}{*}{$\begin{array}{c}\mathbf{N}-\mathbf{I} \\
\left({ }^{\circ} \mathbf{C}\right)^{*}\end{array}$} & \multirow{2}{*}{$\Delta \mathbf{T} /{ }^{\mathbf{o}} \mathbf{C}$} & \multicolumn{2}{|c|}{ Transition temperatures, DSC $\left({ }^{\circ} \mathbf{C}\right)$} \\
\cline { 5 - 6 } & & - & - & $\mathbf{T m}$ & $\mathbf{T i}$ \\
\hline $\begin{array}{l}\text { 4-4-di(4-hydroxybutoxy)-N- } \\
\text { benzylidene-o-tolidine (2a) }\end{array}$ & - & - & - & 242.11 & - \\
\hline $\begin{array}{l}\text { 4-4-di(6-hydroxyhexoxy)-N- } \\
\text { benzylidene-o-tolidine (2b) }\end{array}$ & 160.1 & 275.2 & 115.1 & 160.0 & 285.10 \\
\hline $\begin{array}{l}\text { 4-4-di(8-hydroxyoctoxy)-N- } \\
\text { benzylidene-o-tolidine (2c) }\end{array}$ & 126.0 & 231.0 & 105.0 & 130.0 & 228.0 \\
\hline $\begin{array}{l}\text { 4-4-di(10-hydroxydecoxy)-N- } \\
\text { benzylidene-o-tolidine (2d) }\end{array}$ & 103.0 & 251.0 & 148.0 & 105.0 & 257.0 \\
\hline
\end{tabular}

$\mathrm{Cr}=$ crystal; $\mathrm{N}=$ Nematic phase; $\mathrm{I}=$ isotropic; * = as observed under POM.

\section{Experimental}

\subsection{Materials}

Unless otherwise stated, all chemicals were commercially obtained and used without further purification or distillation: o-tolidine (Fluka, Germany), 4-hydroxybenzaldehyde (MERCK, Germany), 4-chloro-1-butanol (Fluka, Germany), 6-chloro-1-hexanol (Fluka, Germany), 8-chloro-1-octanol 
(Sigma Aldrich, Germany), 10-chloro-1-decanol (Sigma Aldrich, Germany), potassium carbonate (Fisher Chemicals, UK), absolute ethanol 99.5\% (Systerm ${ }^{\circledR}$, Malaysia), 1-butanol 99.5\% (R\&M Chemicals, Malaysia), $N, N$-dimethylformamide (Systerm ${ }^{\circledR}$, Malaysia)

\subsection{Instrumentation}

FT-IR spectra were measured using a Perkin-Elmer 2000 FTIR equipped with a potassium bromide $(\mathrm{KBr})$ beam splitter. Thirty-two (32) scans were collected between $4000 \mathrm{~cm}^{-1}$ and $400 \mathrm{~cm}^{-1}$ with a resolution of $2.0 \mathrm{~cm}^{-1}$. The ${ }^{1} \mathrm{H}-\mathrm{NMR}$ and ${ }^{13} \mathrm{C}$-NMR spectra were obtained using a Bruker $400 \mathrm{MHz}$ and a $300 \mathrm{MHz}$ spectrometer. The samples were prepared at $100 \mathrm{mg} / \mathrm{mL}$ in $\mathrm{CDCl}_{3}$ with tetramethylsilane (TMS) as the internal reference. CHN microanalyses were performed using a Perkin Elmer 2400 LS Series $\mathrm{CHNS}=\mathrm{O}$ analyzer. Differential scanning calorimetry (DSC) studies were carried out with a Perkin-Elmer DSC7 series at heating rate of $5{ }^{\circ} \mathrm{C} / \mathrm{min}$ in nitrogen, Melting points of LC monomers were obtained based on the peak of the melting temperatures from DSC analysis. Polarizing optical microscope (POM), a Carl Zeiss Axioskop equipped with 40 Linkam LTS350 hot stage, Linkam TMS94 temperature controller and Linkam LNP cooling system (pump) was used to determine the liquid crystalline mesophase. Thermal stability was studied using Perkin-Elmer TGA-7 under $\mathrm{N}_{2}$ atmosphere. The heating rate was programmed to $5{ }^{\circ} \mathrm{C} / \mathrm{min}$ and it was performed at the temperature range of $30-900^{\circ} \mathrm{C}$.

\subsection{Preparation of Bisphenol N,N'-bis(4-hydroxy)-benzylidene-o-tolidine (1).}

p-Hydroxybenzaldehyde (12.21 g, $0.10 \mathrm{~mol})$ was added dropwise into a solution of $o$-tolidine $(10.61 \mathrm{~g}, 0.05 \mathrm{~mol})$ in absolute ethanol $(60 \mathrm{~mL})$ in a $500 \mathrm{~mL}$ reaction flask. The mixture was refluxed for $6 \mathrm{~h}$ with magnetic stirring. The product was then filtered, washed several times with diethyl ether and dried in the vacuum oven at $70{ }^{\circ} \mathrm{C}$. Final purification was carried out by recrystallization using 1-butanol to give yellow crystals. Yield was $74 \%$ with a melting point of 281-282 ${ }^{\circ} \mathrm{C}$. FT-IR (KBr disc): $3,414 \mathrm{~cm}^{-1}$ (O-H stretch), $1,608 \mathrm{~cm}^{-1}\left(\mathrm{C}=\mathrm{N}\right.$ stretch), $1,516 \mathrm{~cm}^{-1}(\mathrm{C}=\mathrm{C}$ stretch). ${ }^{1} \mathrm{H}-\mathrm{NMR}(400 \mathrm{MHz}): \delta 8.56(\mathrm{~s}, 2 \mathrm{H}, \mathrm{H}-\mathrm{C}=\mathrm{N}), 6.05(2 \mathrm{H},-\mathrm{OH}), 7.79-6.85(\mathrm{dd}, 8 \mathrm{H}$, aromatic protons), $7.35(\mathrm{~d}, 2 \mathrm{H}$, aromatic protons), $7.27(\mathrm{~d}, 2 \mathrm{H}$, aromatic protons), $7.76(\mathrm{~s}, 2 \mathrm{H}$, aromatic protons), $2.34\left(\mathrm{~s}, 6 \mathrm{H}, \mathrm{Ph}-\mathrm{CH}_{3}\right) \mathrm{ppm} .{ }^{13} \mathrm{C}-\mathrm{NMR}\left(\mathrm{CDCl}_{3}\right): \delta 18.64,116.21,122.68,126.34,129.12$, $130.62,131.08,132.14,141.24,151.36,160.58,161.23 \mathrm{ppm}$.

\subsection{Preparation of mesogenic diols $\mathbf{2}(\mathbf{a}-\mathbf{d})$}

Chloroalkanol $(0.40 \mathrm{~mol})$ and sodium carbonate $(0.45 \mathrm{~mol})$ were dissolved in DMF $(400 \mathrm{~mL})$. Bisphenol $1(0.20 \mathrm{~mol})$ in DMF $(60 \mathrm{~mL})$ was added in the above mixture in a $500 \mathrm{~mL}$ reaction flask. The mixture was refluxed at $130{ }^{\circ} \mathrm{C}$ for $12 \mathrm{~h}$. The product was precipitated by pouring the obtained solution into cold distilled water $(2 \mathrm{~L})$. The precipitate was then filtered, washed several times with diethyl ether and dried in a vacuum oven at $90{ }^{\circ} \mathrm{C}$. Final purification was carried out by recrystallization using the mixture solvent of DMF-butanol (1:1).

4,4'-di(4-Hydroxybutoxy)- $N$-benzylidine-o-tolidine (2a). Colour: yellow. Yield: $58 \%$. Melting point: 242-244 ${ }^{\circ} \mathrm{C}$. FT-IR (KBr disc): 3,414 $\mathrm{cm}^{-1}$ (O-H stretch), 1,607 $\mathrm{cm}^{-1}\left(\mathrm{C}=\mathrm{N}\right.$ stretch), $1,509 \mathrm{~cm}^{-1}(\mathrm{C}=\mathrm{C}$ 
stretch). ${ }^{1} \mathrm{H}-\mathrm{NMR}(400 \mathrm{MHz}): \delta 8.37(\mathrm{~s}, 2 \mathrm{H},-\mathrm{CH}=\mathrm{N}), 7.87-6.98$ (dd, 8H, aromatic protons), 7.50 (d, $2 \mathrm{H}$, aromatic protons), 7.45 (d, 2H, aromatic protons), 7.85 (s, 2H, aromatic protons), 4.03 (t, 4H, -O$\mathrm{CH}_{2}$ ), 3.65 (m, 4H, HO- $\mathrm{CH}_{2-}$ ), 2.41 (s, 6H, $\left.\mathrm{Ph}-\mathrm{CH}_{3}\right), 1.89-1.49$ (m, 8H, $-\mathrm{CH}_{2}-$ protons) ppm. ${ }^{13} \mathrm{C}-$ $\mathrm{NMR}\left(\mathrm{CDCl}_{3}\right): \delta 18.5\left(\mathrm{Ph}-\mathrm{CH}_{3}\right), 25.57-32.31 \quad\left(-\mathrm{CH}_{2}-\right), 62.00 \quad\left(-\mathrm{O}-\mathrm{CH}_{2}-\right), 69.54\left(-\mathrm{CH}_{2}-\mathrm{OH}\right)$, 114.0-160.74 (aromatic carbons), $162.24(-\mathrm{CH}=\mathrm{N}-)$ ppm. Elemental analysis: found: $\mathrm{C}, 76.43 ; \mathrm{H}$, 7.14; N, 5.06, $\mathrm{C}_{36} \mathrm{H}_{40} \mathrm{~N}_{2} \mathrm{O}_{4}$.Calcd: C, 76.59; H, 7.09; N, 4.96.

4,4'-di(6-Hydroxyhexoxy)-N-benzylidine-o-tolidine (2b). Colour: Brown. Yield: 70\%. Melting point: 160-162 ${ }^{\circ} \mathrm{C}$. FT-IR (KBr disc): 3,419 $\mathrm{cm}^{-1}$ (O-H stretch), $1,621 \mathrm{~cm}^{-1}\left(\mathrm{C}=\mathrm{N}\right.$ stretch), $1,509 \mathrm{~cm}^{-1}(\mathrm{C}=\mathrm{C}$ stretch). ${ }^{1} \mathrm{H}-\mathrm{NMR}(400 \mathrm{MHz}): \delta 8.35(\mathrm{~s}, 2 \mathrm{H},-\mathrm{CH}=\mathrm{N}), 7.90-7.02(\mathrm{dd}, 8 \mathrm{H}$, aromatic protons), 7.51 (d, $2 \mathrm{H}$, aromatic protons), $7.49(\mathrm{~d}, 2 \mathrm{H}$, aromatic protons), 7.87 (s, 2H, aromatic protons), 4.05 (t, $4 \mathrm{H}$, -O$\mathrm{CH}_{2}$ ), 3.65 (m, 4H, HO- $\left.\mathrm{CH}_{2}-\right), 2.41\left(\mathrm{~s}, 6 \mathrm{H}, \mathrm{Ph}-\mathrm{CH}_{3}\right), 1.90-1.30$ (m, $16 \mathrm{H},-\mathrm{CH}_{2}-$ protons) ppm. ${ }^{13} \mathrm{C}-$ $\mathrm{NMR}\left(\mathrm{CDCl}_{3}\right): \delta 18.52\left(\mathrm{Ph}-\mathrm{CH}_{3}\right), 25.57-32.31\left(-\mathrm{CH}_{2}^{-}\right), 62.65\left(-\mathrm{O}-\mathrm{CH}_{2}-\right), 68.64\left(-\mathrm{CH}_{2}-\mathrm{OH}\right)$, 114.43-158.74 (aromatic carbons), $161.24(-\mathrm{CH}=\mathrm{N}-)$ ppm. Elemental analysis: found: C, 77.30; H, 7.79; N, 4.50, $\mathrm{C}_{40} \mathrm{H}_{48} \mathrm{~N}_{2} \mathrm{O}_{4}$.Calcd: C, 77.14; H, 7.74; N, 4.51.

4,4'-di(8-Hydroxyoctoxy)- $N$-benzylidine-o-tolidine (2c). Colour: yellow. Yield: $68 \%$. Melting point: 119-120 ${ }^{\circ} \mathrm{C}$. FT-IR (KBr disc): 3,419 $\mathrm{cm}^{-1}$ (O-H stretch), $1,621 \mathrm{~cm}^{-1}\left(\mathrm{C}=\mathrm{N}\right.$ stretch), $1,509 \mathrm{~cm}^{-1}(\mathrm{C}=\mathrm{C}$ stretch). ${ }^{1} \mathrm{H}-\mathrm{NMR}\left(400 \mathrm{MHz}, \mathrm{CDCl}_{3}\right): \delta 8.35(\mathrm{~s}, 2 \mathrm{H},-\mathrm{CH}=\mathrm{N}), 7.90-6.96$ (dd, 8H, aromatic protons), $7.49(\mathrm{~d}, 2 \mathrm{H}$, aromatic protons), $7.46(\mathrm{~d}, 2 \mathrm{H}$, aromatic protons), $7.88(\mathrm{~s}, 2 \mathrm{H}$, aromatic protons), $4.02(\mathrm{t}$, $\left.4 \mathrm{H},-\mathrm{O}-\mathrm{CH}_{2}-\right), 3.66$ (m, 4H, HO- $\left.\mathrm{CH}_{2-}\right), 2.42\left(\mathrm{~s}, 6 \mathrm{H}, \mathrm{Ph}-\mathrm{CH}_{3}\right), 1.86-1.29$ (m, 24H, $-\mathrm{CH}_{2}$ - protons) ppm. ${ }^{13} \mathrm{C}-\mathrm{NMR}\left(\mathrm{CDCl}_{3}\right): \delta 18.5\left(\mathrm{Ph}_{-} \mathrm{CH}_{3}\right), 25.57-32.31\left(-\mathrm{CH}_{2}-\right), 62.00\left(-\mathrm{O}-\mathrm{CH}_{2}-\right), 69.54\left(-\mathrm{CH}_{2}-\mathrm{OH}\right)$, 114.50-160.45 (aromatic carbons), $162.40(-\mathrm{CH}=\mathrm{N}-)$ ppm. Elemental analysis: found: $\mathrm{C}, 78.28 ; \mathrm{H}$, 8.11; N, 4.20, $\mathrm{C}_{44} \mathrm{H}_{56} \mathrm{~N}_{2} \mathrm{O}_{4}$.Calcd: C, 78.1; H, 8.28; N, 4.14.

4,4'-di(10-Hydroxydecoxy)-N-benzylidine-o-tolidine (2d). Colour: yellow. Yield: $81 \%$. Melting point: 108-109 ${ }^{\circ} \mathrm{C}$. FT-IR (KBr disc): $3,353 \mathrm{~cm}^{-1}$ (O-H stretch), $2931 \mathrm{~cm}^{-1}, 2,862 \mathrm{~cm}^{-1}, 1,620 \mathrm{~cm}^{-1}(\mathrm{C}=\mathrm{N}$ stretch), $1509 \mathrm{~cm}^{-1}\left(\mathrm{C}=\mathrm{C}\right.$ stretch). ${ }^{1} \mathrm{H}-\mathrm{NMR}\left(400 \mathrm{MHz}, \mathrm{CDCl}_{3}\right): \delta 8.39(\mathrm{~s}, 2 \mathrm{H},-\mathrm{CH}=\mathrm{N}), 7.92-6.98(\mathrm{dd}$, $8 \mathrm{H}$, aromatic protons), $7.51(\mathrm{~d}, 2 \mathrm{H}$, aromatic protons), $7.49(\mathrm{~d}, 2 \mathrm{H}$, aromatic protons), $7.88(\mathrm{~s}, 2 \mathrm{H}$, aromatic protons), 4.07 (t, 4H, $\left.-\mathrm{O}-\mathrm{CH}_{2}-\right), 3.68$ (m, 4H, $\left.\mathrm{HO}-\mathrm{CH}_{2}-\right), 2.46\left(\mathrm{~s}, 6 \mathrm{H}, \mathrm{Ph}_{-} \mathrm{CH}_{3}\right), 1.89-1.25$ (m, $32 \mathrm{H},-\mathrm{CH}_{2}$ - protons) ppm. ${ }^{13} \mathrm{C}-\mathrm{NMR}\left(\mathrm{CDCl}_{3}\right) \delta 18.5\left(\mathrm{Ph}_{-} \mathrm{CH}_{3}\right), 25.57-32.31\left(-\mathrm{CH}_{2}-\right), 62.00\left(-\mathrm{O}-\mathrm{CH}_{2}-\right)$, $69.54\left(-\mathrm{CH}_{2}-\mathrm{OH}\right), 114.0-160.74$ (aromatic carbons), $162.24(-\mathrm{CH}=\mathrm{N}-)$ ppm. Elemental analysis: found: C, 78.60; H, 8.90; N, 3.80, $\mathrm{C}_{48} \mathrm{H}_{64} \mathrm{~N}_{2} \mathrm{O}_{4}$.Calcd: C, 78.68; H, 8.74; N, 3.82.

\section{Conclusions}

A series of $N, N^{\prime}$-bis(4-hydroxyl)benzylidine-o-tolidine compounds with various alkyl chain lengths $(4,6,8$, and 10), was successfully synthesized. The diols were found to demonstrate enantiotropic nematic phase based on the POM and DSC observations. Diols $\mathbf{2 b}$ and $\mathbf{2 d}$ exhibit enantiotropic nematic liquid crystal phase (marble texture and shredded texture respectively) but diol 2a did not exhibit any liquid crystalline phase, while the diol 2c exhibits a smectic mesophase. DSC analyses showed that the increase in alkyl chain length in diols will result in a the decrease in the transition temperature for this series of compounds. 


\section{Acknowledgements}

The authors would like to thank Universiti Sains Malaysia for RU research grant No.PTEKIND/33399/11900

\section{References}

1. Issam, A.M.; Ismail, J. New aromatic poly(azomethine urethane)s containing $o$-tolidine moiety in the polymer backbone. Des. Monomers Polym. 2006, 9, 237-246.

2. Sudhakar, S.; Narasimhaswamy, T.; Srinivasan, K.S.V. Towards the molecular-statistical modelling of the optically isotropic mesophase in neat systems: from the thermodynamic point of view. Liq. Cryst. 2000, 27, 1525-1559.

3. Samaresh, G.; Banthia A.K.; Zhu, C. Synthesis and photoresponsive study of azobenzene centered polyamidoamine dendrimers. Tetrahedron 2005, 61, 2889-2896.

4. Issam, A.M. Synthesis of novel Y-type polyurethane containing azomethiine moiety, as non-linear optical chromophore and their properties. Eur. Polym. J. 2007, 43, 214-219.

5. So, B.K.; Kim, W.J.; Lee, S.M.; Jang, M.C.; Song, H.H.; Park. J. H. Novel bent-shaped liquid crystalline compounds: III. Synthesis of Schiff base liquid crystal dimer. Dyes Pigm. 2007, 75, 619-623.

6. Bruice, P.Y. Infrared Spectroscopy, and NMR Spectroscopy. In Organic Chemistry; Pearson Education International: New Jersey, USA, 2004; pp. 482-592.

7. Unaleroglu, C.; Hokelek, T. The Crystal Structure and Conformational Analysis of N,N'-Bis(5Bromo-2-Hydroxy-Benzylidene)Ethylenediamine. Spectrosc. Lett. 2002, 35, 317-326.

8. Stamatoiu, O.; Bubnov, A.; rcomnicu, I.; Iovu, M. Synthesis and spectral characterisation of new amido-ether Schiff bases, J. Mol. Struct. 2008, 886, 187-196.

9. Issam A.M.; Ismail, J. Improvement of thermal stability of new heteroaromatic poly(azomethine urethane)s. J. Appl. Polym. Sci. 2006, 100, 1198-1204.

10. Liu, Y.L.; Zhang, L.; Shi, J.; Cao S.K. Synthesis and characterization of liquid crystalline copolyesters containing horizontal and lateral rods in main chain. React. Funct. Polym. 2005, 64, $35-46$.

11. Prescher, D.; Thiele, T.; Ralf Ruhmann,; Schulz, G. Synthesis of liquid-crystalline poly(methacrylate)s with 4-trifluoromethoxy-azobenzene mesogenic side-groups, J. Fluorine Chem. 1995, 74, 185-189

12. McArdle, C.B. Side Chain Liquid Crystal Polymers. Blackie: Glasgow, UK, 1987; pp.74-75.

13. Perez, F.; Judeinstein, P.; Bayle, J.P. The effect of a lateral aromatic branch on the orientational ordering of laterally alkoxy substituted nematics. Liq. Cryst. 1997, 22, 711-719.

14. Hu, J.S.; Zhang, B.Y.; Zhou, A.J.; Yang, L.Q.; Wang. B. Side-chain cholesteric liquid crystalline elastomers derived from a mesogenic crosslinking agent: I. Synthesis and mesomorphic properties, Eur. Polym. J. 2006, 42, 2849-2858.

15. Chan, L.K.M.; Gray, G.W.; Lacey, D. Synthesis and Evaluation of Some 4,4"-Disubstituted Lateral Fluoro-1,1':4',1"-terphenyls. Mol. Cryst. Liq. Cryst. 1985, 123, 185-204. 
16. Hoshino, H.; Hasegawa, H.; Matsunaga,Y. Mesomorphic properties of orthopalladated complexes of laterally substituted azobenzene derivatives, 2-alkoxycarbonyl-4-(4-ethoxyphenylazo)phenyl 4methoxybenzoates. Liq.Cryst. 1991, 9, 267-276.

17. Berdague, P.; Bayle, J.P.; Ho, M.S.; Fung, B.M. New laterally aromatic branched liquid crystal materials with large nematic ranges. Liq. Cryst. 1993, 14, 667-674.

18. Dave, J.S.; Vora, R.A. Mesomorphic behavior of substituted phenylbenzoates- I: p(p'-nalkoxybenzoyloxy) toluenes. Pramana 1975, Supplement 1, 447.

Sample Availability: Not available.

(C) 2010 by the authors; licensee MDPI, Basel, Switzerland. This article is an open-access article distributed under the terms and conditions of the Creative Commons Attribution license (http://creativecommons.org/licenses/by/3.0/). 